\title{
Li Xiangping, Xinyang dan bu rentong: dangdai zhongguo xinyang de shehuixue quanshi
}

(Believing without Identifying: The Sociological Interpretation of Spiritual Beliefs in Contemporary China), Beijing, Social Sciences Academic Press, 2010.

Nanlai Cao

\section{(2) OpenEdition}

\section{Journals}

\section{Electronic version}

URL: http://journals.openedition.org/chinaperspectives/5484

DOI: 10.4000/chinaperspectives.5484

ISSN: 1996-4617

\section{Publisher}

Centre d'étude français sur la Chine contemporaine

\section{Printed version}

Date of publication: 1 January 2011

Number of pages: $92-93$

ISSN: 2070-3449

\section{Electronic reference}

Nanlai Cao, «Li Xiangping, Xinyang dan bu rentong: dangdai zhongguo xinyang de shehuixue quanshi», China Perspectives [Online], 2011/1 | 2011, Online since 30 March 2011, connection on 21 September 2020. URL : http://journals.openedition.org/chinaperspectives/5484 ; DOI : https://doi.org/10.4000/ chinaperspectives.5484

This text was automatically generated on 21 September 2020.

(c) All rights reserved 


\section{Li Xiangping, Xinyang dan bu rentong: dangdai zhongguo xinyang de shehuixue quanshi}

(Believing without Identifying: The Sociological Interpretation of Spiritual Beliefs in Contemporary China), Beijing, Social Sciences Academic Press, 2010.

\section{Nanlai Cao}

1 Li Xiangping has made important contributions to the development of the sociology of religion in China by pointing out the socially and historically embedded nature of religious belief in a series of Chinese-language publications. His latest book, Believing without Identifying: The Sociological Interpretation of Spiritual Beliefs in Contemporary China, urges people to focus on various religious, spiritual, cultural, and political beliefs as social phenomena and forms of social relationship and to gain a deeper understanding of the broader historical context from which contemporary Chinese practices of belief emerged. This thought-provoking book is a revised collection of his work spanning a three-

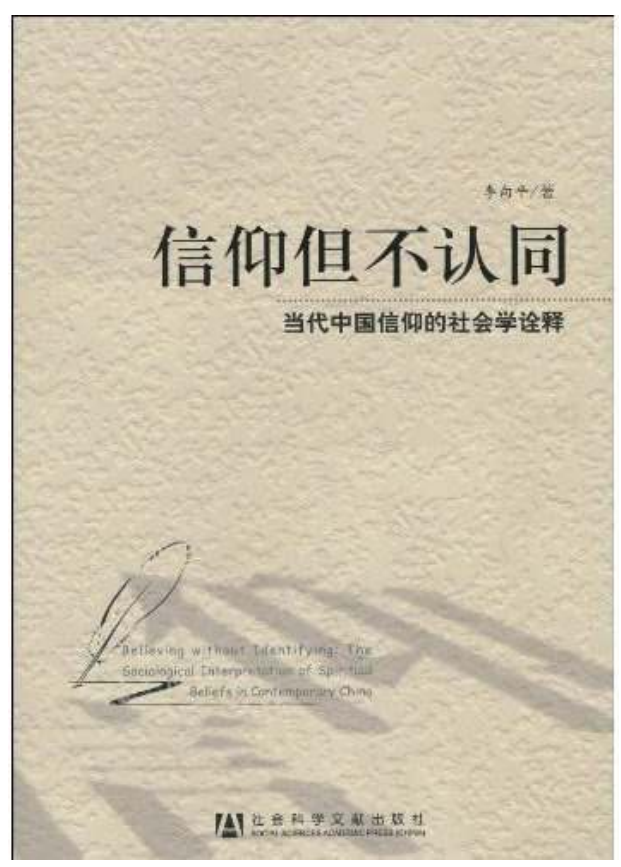
year period. It includes unpublished work as well as essays published previously in academic journals and newspapers, and also draws on lectures and presentations he has given at various conferences. Framed by arguments concerning issues of belief and the social aspects of religious practice in 
contemporary China, the book is divided into four thematic sections: "The historical transformation of Chinese beliefs," "belief and the rise of Chinese modernity," "identity of belief and distinctions in belief," and "the basic structure of a sociology of belief."

The author draws on popular media materials, insightful anecdote observations, faceto-face interviews, and historical and literary texts to explore how the beliefs of the Chinese are articulated, practiced, contested, and confirmed as they relate to the complex interactions between power, social status, and identity in contemporary China. His larger structural concerns throughout the book mark a departure from the traditional doctrinal-textual approach to the study of religion in China.

3 Li draws a careful distinction between religion (zongjiao) and belief (xinyang), and points out that "religion is not the main organizing principle of Chinese civilization but various types of belief are, be they cultural, religious, ethnic, political, or folk" (p. 43). According to him, it is only through such institutional mediums as the state, race or ethnicity, religion, rural grassroots organisation, social status, and identity that belief takes various socially definable and recognised forms (e.g., cultural belief, political belief, ethnic/racial belief, religious belief, and folk belief). He employs the hair-skin metaphor to refer to the closely intertwined relationship between (inner) belief and the underlying social mechanisms. Furthermore, he argues that diverse phenomena of belief reflect unequal power relations, because without the affirmation and protection of a corresponding social identity and status, one's belief cannot be mobilised as a resource for social participation and the construction of daily life. He suggests that inner belief should not be taken as a proper object of sociological analysis on its own but must be studied in relation to the social-political milieu in which it is embedded. Therefore, as he contends, what sociologists should be concerned with is not the Chinese lack of beliefs or a commonly discussed "spiritual vacuum" in the post-Mao period, but how people come to believe and practice their beliefs as well as the social implications of such practices.

The book has significant implications for practicing the sociology of religion in China.

5 As a Chinese scholar who was trained initially as a historian before practicing as a sociologist of religion, Li succeeds in his aim of placing the practices of belief in a wider disciplinary context. He defines what he calls "sociology of belief" as a research field focused on not just institutionalised religion but also privatised belief, syncretised religion, religion-state relations, and inter-faith relationships. For him, this sociology of belief should aim at understanding "the enabling effects of beliefs on Chinese politics, thought, religion and spiritual care" (p. 181).

6 As a seasoned commentator and regular contributor to the liberal national magazine Nanfeng Chuang (South Wind Window), Li writes from the position of a public sociologist who constantly confronts the challenges of presenting empirical examples (especially high-profile events) to the general public in conceptual terms. In a strong position to promote general sociology and social analysis in religious research in China, Li extends the scope of the narrowly defined sociology of religion to incorporate non-religious beliefs embedded in the complex networks of social and personal relationships. The study of religion can thus be perfectly subsumed into the study of belief in general. This conceptual broadening is highly laudable, especially considering the fact that the positivist tradition imported from the United States is so influential across almost all social science disciplines in China today. Specifically, it will help counter the current 
imbalance towards a social demographic approach to religious life in the field of Chinese sociology.

There is a growing trend for native Chinese sociologists of religion to be more scientific in methodology by catching up with their American counterparts in quantitative survey research. Large-scale surveys have been conducted in China to depict and understand patterns of religious identification among the general population. However, this type of research is often carried out by students with minimal knowledge of religious practice in everyday life. Statistically sophisticated researchers often neglect the fact that many terms used in China, such as religion, while referring to phenomena worldwide, are imported concepts. In contrast to anthropologists who usually embrace a local studies tradition, today's sociologists have not paid enough attention to terms and categories derived from immediate Chinese realities. By replacing the loaded modern Western concept of religion with the more culturally sensitive term of belief as the most basic unit of analysis, the author shows how various beliefs link individual Chinese to the creative production of social identities and relationships. Li addresses a wide range of issues with reference to the production and meaning of belief in diverse local and national contexts. His wide-ranging discussion includes religion and post-disaster relief and social reconstruction, financial crisis and Buddhist philanthropy, the revival of Confucianism, the Shaolin Temple and its religious economy, the Qingming (Pure Brightness) festival and the ritual economy, Christian entrepreneurs and social trust, the Mao cult and politics of faith, the house church and its legalisation and so forth.

8 The main strength of this book lies in its ability to address the relationships of various religions and spiritual activities to the tensions and concerns of a uniquely Chinese social landscape. Its main theoretical contribution is to draw scholarly attention to the distinctions and connections between beliefs, practices, and institutions in the study of Chinese religiosity. Li's book presents us with a new way to see and do sociology of religion in the contemporary Chinese context, both theoretically and empirically. His "sociology of belief" aspires to offer an intellectual platform for the development of synergy between specialists in Chinese religion and a wider circle of China sociologists.

\section{AUTHOR}

\section{NANLAI CAO}

Research Assistant Professor of the HK Institute for the Humanities \& Social Sciences, The University of Hong Kong. 